\title{
SRPX2 Gene
}

National Cancer Institute

\section{Source}

National Cancer Institute. SRPX2 Gene. NCI Thesaurus. Code C24823.

This gene plays a role in the regulation of cancer cell growth. 